Cinémas

Revue d'études cinématographiques

Journal of Film Studies

\title{
Loving Texts Two at a Time : The Film Remake
}

\section{Leonardo Quaresima}

Volume 12, numéro 3, printemps 2002

Cinélekta 4

URI : https://id.erudit.org/iderudit/000736ar

DOI : https://doi.org/10.7202/000736ar

Aller au sommaire du numéro

Éditeur(s)

Cinémas

ISSN

1181-6945 (imprimé)

1705-6500 (numérique)

Découvrir la revue

Citer cet article

Quaresima, L. (2002). Loving Texts Two at a Time : The Film Remake. Cinémas, 12(3), 73-84. https://doi.org/10.7202/000736ar

\section{Résumé de l'article}

Cet essai cherche avant tout à mettre en évidence le peu d'intérêt porté par les théoriciens du cinéma à la notion de remake. L'auteur examine les différents types de remake et les définitions proposées jusqu'ici et isole quelques-uns des traits caractéristiques de cette pratique. Il porte une attention particulière aux modifications que ce remaniement opère sur le texte d'origine. 


\title{
Loving Texts Two at a Time: The Film Remake
}

\section{Leonardo Q uaresima}

\begin{abstract}
RÉSUMÉ
Cet essai cherche avant tout à mettre en évidence le peu d'intérêt porté par les théoriciens du cinéma à la notion de remake. L'auteur examine les différents types de remake et les définitions proposées jusqu'ici et isole quelques-uns des traits caractéristiques de cette pratique. II porte une attention particulière aux modifications que ce remaniement opère sur le texte d'origine.
\end{abstract}

\section{ABST RACT}

This article seeks to illustrate, first of all, how little interest film theory has shown in the notion of the remake. Beginning with a discussion of the principal definitions of the remake and its principal varieties, the author isolates some of the most characteristic practices in the process of remaking. The article draws particular attention to the ways in which the remake alters the original text.

I.

It would be interesting to examine the question of the film remake, not only in its simplest and most common manifestations, but by considering it from the more general perspective of textual plurality. My frame of reference is not so much empirical - that of a film's multiple versions- but is rather more fundamental: that of the multiple or plural quality of the film object itself. Today this quality is more elusive, but in early cinema it was more apparent. Here the originality of a film 
co-existed in perfect harmony with the ability to reproduce it, with the multiplicity of its versions. Responsibility for editing was delegated to the projectionist; this would further reinforce an individual film's multifarious existence. The "work" (the documentary view or the short fiction film) was more an abstract synthesis of different forms of manifestation than a stable entity with its own physiognomy, which could give rise to different versions and forms of corruption (of these, forged and plagiarised copies are the most obvious). From its birth cinema combined the attractions of novelty with repetition. At the same time, in doing so, it freed the "new" from notions of uniqueness and authenticity (except when it was necessary to assert such things for reasons of competition or to protect its legal status). In early cinema, reproducibility was widespread and, so to speak, "natural."

In the succeeding period of stability (Film d'Art, Autorenfilm, the institutionalisation of the feature film and the distribution monopolies, issues concerning copyright) the film took on a status similar to that of other works (of art, or of the culture industry, where the warranty that a work circulated in a certified form was an essential part of the process of institutionalisation and widespread distribution). Yet the seriality of the work's conception and presentation problematises or calls into question this very physiognomy. The international circulation of products fuelled later processes of multiplication, even when "targeted," programmatically differentiated. M oreover, the rapid growth of modes of representation and of institutional models (in addition to models derived from cultural context and taste) brought about widespread practices of remaking and reproducing.

With the arrival of sound films at the end of the 1920s, a seemingly stable situation was again set in motion. H ere too, this occurred under the sign of the multiplication of the forms a single work could take. The multiple versions of the early sound years institutionalised this phenomenon not only on the level of production and representational models but also in the very way, theoretically speaking, that the film "object" was identified. $G$ enre is one area in which this same plurality shows itself. $H$ ere can be found the strongest forms of regulation and institutional- 
isation of it- these forms reach the limit of the notion of work, original, author, and at the same time they avoid crossing this limit.

The remake is a phenomenon both well-known and immediately recognisable (even by the non-specialist). The term is commonly used in everyday language and film publicity campaigns alike, and yet it is a phenomenon whose status is undefined. We might even say that it is a phenomenon which has lacked and continues to lack any theoretical approach. W hat are the reasons for this lack of attention on the level of devising a theoretical approach, of thinking about the remake? It could be the result of the remake's anti-authorship quality. For the remake, value lies in the text (a tale, a story, a subject): in the text's inherent resources, its anonymity, and its independence from authorial guarantees of legitimacy.

Even on the level of its mode of production the remake seems to contradict some of the tidiest models. That of the star system, for example. The remake contradicts the supremacy of the actor and the uniqueness of the movie star- or at least the identification of the actor with his or her character, which is so powerful in the star system. The remake demonstrates (and takes as its starting principle) that Norman Bates, for example, can be divorced from Anthony Perkins. This, if we think about it, is a quite audacious and almost reckless challenge. But there is an even more important reason. As I said at the beginning, the remake calls into question the very notion of an individual work. In this way it resembles, let me point out again, the multiplicity and reproducibility inherent in early cinema, a cinema tolerated as an anomaly, or described as primitive or even as cast aside, effaced. Naturally, plurality in the remake (as it is in genre films) is regulated, identifiable, and motivated. But we still find ourselves in an anomalous aesthetic system in comparison with that promoted by the humanistic conception of the work of art.

If anything, we see in the remake the valorisation of the screenplay, which takes on a status similar to that of the play or musical score. This is, if you like, an act of restoration, returning the film to the traditional models of theatre and music. At the same time, it is an act of audacity, in that it challenges the 
imperatives of originality and novelty (which constitute the foundation of the entire film industry: who goes back to see a film they've already seen?). 0 ut of this, undoubtedly, cinema's allography is reinforced or redoubled (I refer here to $\mathrm{N}$ elson Goodman's definition of the "allographic" and the "autographic," reproposed by Genette in his work L' $\mathbb{E}$ uvre de l'art, 1994 and 1997).

\section{II.}

Let's examine some possible definitions of the remake with respect to other processes which involve relationships among texts and, in particular, with respect to the development of seriality.

We could, first of all, think of the remake as part of a trend, typical of the postmodern, towards nostalgia. This perspective, although it captures one aspect of the phenomenon and helps to interpret it in the present-day context (by which I mean the profusion of remakes in cinema today), does not grasp its true complexity. Rewriting, in the realm of the postmodern, is a common literary practice, but in literature this practice seems far removed from the naïveté, the "virginity," which seems to set such practices apart in cinema. This constitutes proof of the remake's particularity, of its well-defined identity, which can be confirmed after the fact by the absence of the concept of "remake" in literature. In the postmodern aesthetic, rewriting presents itself as a "challenge to the canonical work" (D oležel, 1999, p. 225). Is this an aspect of the film remake? Partly, but more than that is the homage, or the "added value" that text B can derive from its relationship to text $A$. And, unless we find ourselves in a deliberately postmodern context, we do not see, in film, any kind of intended desecration, subversion, or delegitimization.

In the case of the remake, we might adopt the definition that Umberto Eco proposes in his "Tipologia della Ripetizione" (in Casetti, 1984 and Eco, 1985) whereby the remake is seen as a variant of the tracing "to reformulate a popular story without the consumer being made aware of it" (C asetti, 1984, p. 23). The tracing, together with the revival, the series, the saga and the 
phenomena around dialogism, make up a part of the system of seriality. The remake, in this view, is seen as an "explicit and declared tracing" (C asetti, 1984, p. 23).

This however is a purely taxonomic definition. M oreover, in the examples used to illustrate it, rather vague. It does not allow us to advance our discussion. We might then return to Genette's (1982, p. 1) discussion of the phenomena of "transtextuality" (defined as "everything that places a text, visibly or secretly, in relation with other texts") and, in particular, to the hypertextuality which orders the relationship between the original text $\mathrm{A}$ (the hypotext) and the derivative text $B$ (the hypertext). $\mathrm{H}$ ypertextuality can be the product of both direct and indirect transformation (with the latter presupposing the mediation of a system-a genre, for example). Each kind of transformation, when crossed with various systems (the playful, the satirical, the serious), gives rise to six different forms which, in toto, also apply to and locate the various forms of the film remake. This is true in particular in the case of processes of direct transformation in a "serious" system, the rubric under which most aspects of film remakes fall. G enette identifies this process as one of transposition. This term, "transposition," might generate confusion because, in cinema studies, it is most often used to describe the adaptation of a film from a literary work, or a play, a comic strip, etc. But in fact, Genette's schema avoids such ambiguity because it refers only to relationships within a single medium, whereas the examples given above are not only intertextual but also intermedial.

In fact the film remake is often bound up with intermediality; this can be seen, for example, in the case of remaking a television series. But I believe it would be more useful, given the difficulty and state of uncertainty in which we find ourselves, to discuss a limited definition of the remake before moving on to a wider definition which would encompass the notion of intermediality and thus forms of literary (and theatrical, etc.) transposition, in the common sense of the term. The limited definition I propose, then, involves confronting a text B with a prior text A, where both texts belong to the same medium. I don't deny that The Postman Always Rings Twice by Bob Rafelson (1981) could 
be considered a remake of Luchino Visconti's 0 ssessione (1943), but certainly the strongest link between them is their relationship to the novel by James M. Cain. It is this second kind of link which brings us, as I have said, to a wider definition of the remake. But it would be imprudent to tackle this definition before clearing up a few questions about the limited definition.

A recent collection of essays proposes that adaptations of literary texts and plays to the cinema be described as "remakes." This collection is Letteratura e cinema. II remake (Bussi and Chiaro, 1999), published by the Scuola Superiore di Lingue M oderne per Interpreti e Traduttori (The Higher Institute of M odern Languages for Interpreters and Translators) in Forlì (University of Bologna). What we are in the presence of here, I believe, is not so much eager scholarship or the extension of an idea's meaning, but rather a misunderstanding, one which illustrates quite well the difficulty we find ourselves in.

This study is representative, once again, of the backwardness of research into this issue in cinema studies. The critical literature on the remake may seem vast, but it is made up almost entirely of descriptions, or of limited comparative analyses of paired texts, carried out according to the most diverse and unsystematic criteria. Attempts to define the remake are vague and often tautological. And proposals for classifying remakes are sometimes irresistibly (if unwittingly) Borgesian.

The most recent contribution, and certainly the best known, is the book Play it Again, Sam: Retakes on Remakes, edited by Andrew $\mathrm{H}$ orton and Stuart Y. M CD ougal and published by the University of California Press in 1998. Among the numerous essays that make up the volume, one that is noteworthy is Robert Eberwein's "Remakes and Cultural Studies." Eberwein situates the remake within the field of reception studies and sets out a detailed classification schema in which fifteen possible types of remake are identified. This schema starts out with the most sensible and indisputable examples (sound remakes of silent films, colour remakes of black-and-white films, remakes by the same director, U.S. remakes of European films), but finishes off with examples which could only have been inspired by a D ada sensibility, such as: remakes in which the sex of one of 
the characters changes; remakes in which the race of one of the characters changes; and the "remake of a sequel to a film that is itself the subject of multiple remakes" (Eberwein, 1998, p. 30).

A similar classification system (similar in its unintended D ada spirit, I mean) can be found in a special issue of the journal CinémAction. $\mathrm{H}$ ere the field is divided into three categories: films based on films; films based on films which are based in turn on non-film works; and films based on non-film works (Protopopoff and Serceau, 1989, pp. 6-11). But in the introductory essay by guest editor Protopopoff (1989, p. 13), there is a remark which merits further study and which we should pursue: "The remake," Protopopoff writes, "effaces its age." The remake, then, alters the chronology we assign to a film-its "history."

\section{III.}

Let's take stock of and reflect upon the discussion thus far. Genette, in his discussion of literature that refashions an existing literary system (and not "the world"), speaks of processes whereby old forms are invested with new meaning. But it is not even clear if this is what a remake is. At least, in its common form it isn't, for here what is emphasised is updating meaning rather than transforming or reinterpreting it. It is also true that in the film remake the relationship to the pre existing text is one of attempting to obtain proof of legitimacy, to be granted authoritativeness. We are in the presence of a basic technique: the fact that the story already exists gives greater force to the new version. There is here a need to link up with something which already exists, in a manner not unlike that of the sequel. This is a curious thing: the remake, then, is born of a fear of the new (whether this be on the level of the narrative structure or of the film's relationship to its viewers). It is as if an unknown story is seen as a sort of leap in the dark, as a communicative wager that is too risky to undertake.

The remake puts its trust in the plot (independently of the disclosure of the mysteries of the plot and thus similar in a way to the way fables operate). It puts its trust in the characters and the situations. But it can also put its trust in style. In this sense 
the remake reveals cinema to be a highly mannerist medium. This is one topic that should certainly be investigated, and which was suggested in an old issue of the journal Cinema \& Cinema in 1984. The remake distrusts, however, the work's life span. Its starting principle is that the relationship a work establishes with its viewers lasts only briefly. In this sense it introduces considerable anomalies into chronological order and the idea of cinema as a system with a progressive and linear development.

On the other hand, the remake puts its trust in the pleasure of the viewer in juxtaposing and comparing. It assumes that its viewer is an intertextual viewer (in Riffaterre's sense of the term). It bases its own workings on an effet de lecture, on interpretive study - on the possibility that the work will be carried further by the viewer (Samoyault, 2001, p. 16). But is this really the case? This phenomenon is probably restricted to a small circle of cinephilic viewers. The general public seems instead to "acquire" this possibility without ever making use of it and to remain at the level of the most immediate relationship with the film, the superficial level of the story.

\section{IV.}

We have posed only a few questions (and we are not even certain that they are the right questions). 0 ther definitions and other voices can take us further. O ne example is the definition given by Guido Fink (1984), in the issue of Cinema \& Cinema I mentioned above. Fink sees the remake as offering the text a second chance, as a landfall born of the desire to improve a work by adding some elements or removing other, superficial elements. The idea, which he barely sketches out (the suggestion is based on a short story by $\mathrm{H}$ enry James from 1893, "T he M iddle Years"), should be more fully explored. To give a text a second chance, to allow it to fulfil what it wasn't able to do the first time, does not mean simply giving the characters or the situation a new opportunity. It means providing the text, on the level of its formal structure, its narrative organisation, and its very technological means, a second opportunity. The idea of a second chance, also developed from an analysis of methods of 
adaptation, of the relationship between cinema and literature, seems to me to be a seductive one just the same. It is a second opportunity offered to the same characters to re-enact a gesture, reconsider a choice, relive an adventure, while retaining the memory of the previous adventure or, better yet, remaining wiser from the previous experience. This is an analytical model which has not yet been adequately developed.

$O$ ne of the most precise theoretical formulations of the remake comes, unexpectedly, from a text by Borges entitled "Pierre M énard, autor del Q uijote" (which G enette, among others, has drawn authoritative attention to), in his book Ficciones (1944). The narrator of this piece rewrites, in identical fashion, Cervantes' masterpiece. And this rewriting - which, I repeat, is identical-makes it possible for the text to enter into a new and completely different context. Reformulated in the twentieth century, Cervantes' expressions acquire completely different meanings. The style of the novel itself seems different.

Borges' extreme example (but not entirely unique: Gus Van Sant did something similar with $\mathrm{H}$ itchcock's Psycho) reveals a fundamental aspect of every process of remaking: the text is put in a different network of meaning and different cultural systems. Every remake, then, is a recontextualisation, an insertion of the text into a new network of circumstances, independently of any way in which the text may be updated (in the case of $M$ énard's $D$ on Q uixote, there is no updating whatsoever). This reproposal of the work, understood as a creative act and not as a copying or re-issuing, alters the work even if it remains identical to itself. The remake thus seems to function as a reconfiguring of the original text into a new, contemporary setting, where nothing is as it was the first time around. Under the guise of repetition, the remake surreptitiously introduces a system of generalised novelty and originality, which becomes all the more remarkable the greater the similarity of the text to the original.

The remake (Borges again) manifests itself under the sign of anachronism, corresponding to the shifting forward of a text and its operativity. To remake is the equivalent of altering the natural order of film history, as it alters literary history. It functions by tearing a text out of the chronological position it has been 
assigned and relocating it in the present, reformulating every aspect of its meaning and style. This rending may be irreparable, and the text thereby isolated will be marked for all time by this temporal extraterritoriality. Borges' observations were for the most part concerned with a work's textual dimension. But if we examine the ideas of Lubomír D oležel in his book H eterocosmica (1998), we find a different suggestion: to refer, for processes associated with the remake, to fictional worlds, to universes which "gain a semiotic existence independent of the constructing texture" (p. 202). These worlds interact, moreover, with an "active cultural memory," however autonomous or independent of the form of the original narration. This is the model of transduction, which enjoins the processes that construct a fictional world, and which we should take into consideration here.

What is interesting about D oležel's proposal is that it confirms the central role of achronia in the process of creating a remake. In this context, rewriting is al ways a "challenge to the past" (D oležel, 1998, p. 206). By re-examining this passage, and other earlier clues, we can see that the idea of reworking a past work is foreign to the remake. In fact the very idea of the past is effaced. We are thus dealing with a phenomenon that is completely distinct from "second degree literature," which is of the same order as critical commentary and creates historical distance. In the remake, the fact that a given subject was filmed ten, fifteen or twenty years earlier appears accidental. The gesture of recuperation seems to want to redeem the subject from having been deployed too soon.

D oležel identifies three kinds of rewriting, which correspond to three situations in the fictional worlds. The first is that of "parallel worlds," in which "transposition preserves the design and the main story of the protoworld [that is, of the original world], but locates it in a different spatial or temporal environment" (D oležel, 1998, p. 206). The second is that of "complementary worlds," where expansion "extends the scope of the protoworld by filling its gaps, constructing a prehistory or a posthistory" (p. 207). And the third is that of "polemic worlds," in which displacement "constructs an essentially different version of the protoworld, redesigning its structure and reinventing its story" (p. 207). This approach interprets the issue of the film remake in a highly persuasive way. 
M oreover, by taking our cue from the processes pointed out by the author with reference to the rewriting of texts which belong to the Western "canon," we can conjecture that a relationship between text and classic text is al ways present in the remake, in the sense that the remake al ways treats the text it acts upon as classic. Remaking extracts a text from the continuum of film history and gives it an ulterior, added value. But not only this. It transforms the text into a classic text, that is into an object in which linguistic forms and elements of meaning act in a canonical, stylised fashion. In many texts (hypotexts or protoworlds) this is a fundamental operation and transformation. The heart of this process consists of attributing to the original system the quality of a mythic tale and establishing its elements as archetypes.

We might think of this as another peculiarity of the remake, whose outcomes and repercussions concern the text being subjected to rewriting and refashioning. This process can manifest itself in the context of an intermedial rewriting (such as making a film out of a literary text), but it is the remake which marks a decisive turn in this sense. In literature, moreover, the kind of rewriting that takes place al ways "activates as a cognitive background the fictional encyclopedia" (D oležel, 1998, p. 222) of the classic original world. This is less true in the cinema: the classic quality of the text being rewritten is more often established by the act of rewriting itself.

V.

We have, perhaps, taken a few steps forward. We have identified a few phenomena which are closely linked to the practice of remaking and which are capable of accounting for its widespread use and effectiveness. We are thus in a position to broach the opacity of this topic. Twenty years ago, in his Palimpsetes, $G$ enette reclaimed pleasure and defended the desire to love "texts two at a time." He spoke of an "open structuralism," of a "palimpsestuous reading" (1982, p. 557). It seems to me that few people, and not only in cinema studies, have responded to this challenge and this seduction.

Translated by Rachel Reid and T imothy Barnard

University of $\mathrm{U}$ dine 


\section{BIBLIO GRAPHICAL REFERENCES}

Borges, 1981: Jorge Luis Borges,"Pierre M énard autor del Quijote," O bras Completas, Barcelona, M aría Kodona y Emecé, [1944] 1981, pp. 444-450.

Bussi and Chiaro, 1999: Elisa Bussi and D elia Chiaro (eds.), Letteratura e cinema. II Remake, Bologna, Clueb, 1999.

C asetti, 1984: Francesco C asetti (ed.), L'immagineal plurale, Venice, M arsilio, 1984.

Doležel, 1998: Lubomír D oležel, H eterocosmica: Fiction and Possible Worlds, Baltimore, Johns H opkins U niversity Press, 1998.

Eberwein, 1998: Robert Eberwein, "Remakes and Cultural Studies," in Andrew Horton and Stuart Y. M CD ougal (eds.), Play it Again, Sam: Retakes on Remakes, Berkeley, U niversity of C alifornia Press, 1998.

Eco, 1985: U mberto Eco, Sugli specchi ealtri saggi, M ilan, Bompiani, 1985.

Fink, 1984: Guido Fink, "Elogio della seconda chance," Cinema \& Cinema, no. 39, 1984.

G enette, 1982: G érard G enette, Palimpsestes, Paris, Seuil, 1982.

Genette, 1994: G érard Genette, L'CF uvre de l'art I. Immanence et transcendance, Paris, Seuil, 1994.

Genette, 1997: G érard G enette, L'吕 uvre del'art II. La relation esthétique, Paris, Seuil, 1997.

Goodman, 1968: Nelson Goodman, Languages of Art, Indianapolis, The BobbsM errill, 1968.

H orton and M CD ougal, 1998: Andrew H orton and Stuart Y. M CD ougal (eds.), Play it Again, Sam: Retakes on Remakes, Berkeley, U niversity of C alifornia Press, 1998.

Protopopoff and Serceau, 1989: M ichel Serceau and D aniel Protopopoff (eds.), "Le remake et l'adaptation," special issue of CinémAction, no. 53, 1989.

Riffaterre, 1979: M ichael Riffaterre, La Production du texte, Paris, Seuil, 1979.

Riffaterre, 1983: M ichael Riffaterre, Sémiotique de la poésie, Paris, Seuil, 1983.

Samoyault, 2001: Tiphaine Samoyault, L'Intertextualité. M émoire de la littérature, Paris, N athan, 2001. 